\title{
Tax Revenue Prediction under Condition of Imperfect Control over Tax-Collecting Authority $^{\#}$
}

\author{
Stanislav Klazar*
}

\section{Introduction}

Appropriate public revenue forecasts are crucial for long term (commonly defined for period longer then decade) and middle term (longer then budgeting period, commonly one year) public budgeting. Only unbiased and accurate revenue forecasts enable government to set up effective public expenditure programs based on the equality of marginal costs and marginal benefit.

Forecasting authority has to meet many difficulties during the forecasting process. It knows only uncompleted set of information about the explanatory economic and social variables which have influence on the future public revenue. It usually results in not exact (not very accurate) but still unbiased forecasts. On the other side the modern public theory (in last decade) recognizes some reasons for the biased (systematically over a long period and intentionally) forecasts. Contemporary research focuses on the study of rationale for systematically overstated or understated revenue forecasts, moreover some economists suppose that biased forecast can be more harmful then some extend of inaccuracy for the efficiency of public finance.

This paper analyzes the possible reasons for biased tax revenue forecasts. We modified the theoretical model derived by Danninger (2005) to test some of its implications with data for the Czech Republic. Our modification of Danninger's theoretical model demonstrates that systematically and intentionally biased revenue forecasts can be the result of the government's (Principal's) attempt to increase the effort of tax-collecting authority (Agent) to collect more revenue.

The remainder of this paper is structured as follows. Section 2 - Review of related literature is followed by Section 3 - Model, which summarizes the main assumptions and results of the proposed explanation for biased forecasts. This analysis is based on theoretical model. The other Section 4 - Empirical analysis discusses case study evidence from Czech Republic. The final section concludes.

\# This article, which has been elaborated as one of the outcomes of research project registered with the Grant Agency of the Czech Republic under reg. no. 402/04/1069. I would like to thank RNDr. Avgustina Celikovská, head of Department of tax administration and tax analysis of Ministry of Finance for provision the specific data from the ADIS database and Ing. Barbora Slintáková, PhD., researcher from the Department of Public Finance, University of Economics, Prague, for her useful comments concerning the Principal-Agent theory and its application in public finance.

* Ing. Stanislav Klazar, Ph.D. - senior lecturer; Department of Public Finance, Faculty of Finance and Accounting, University of Economics, Prague, nám. W. Churchilla 4, 13067 Praha 3, Czech Republic; <klazar@vse.cz>. 


\section{Review of related literature}

Only few papers have directly analysed the rationale for biased forecasts. Prevalence of papers studies the accuracy of forecasting, but the rationale for biased forecasts remained outside the main research trends (especially for the lack of data and econometrical methods). They almost exclusively addressed only the technical aspects of the forecast (Auerbach, 1999 or Pike et al., 1998).

Some of the first and most inspiring attempts to look for the rationale of biased forecasts in public finance can be found in Holmström (1979) and Grosmann, Hart (1983). They suggest employing the standard solutions from the principal-agent theory. Danninger (2005) follows and further cultivates their thoughts. Some attempts to test empirically the existence of biased forecasts can be found in Zellner (1986) and Feenberg et al. (1989).

Some modest attempts of similar testing in the Czech Republic are presented in Klazar (2003) or Špalek (2002).

Biased forecasts are not only the phenomenon in the public budgeting process. Some research concentrates on the performance of private market forecasters. A paper by Laster et al. (1999) illustrates that private sector forecasters behave strategically and do not provide (in public) their true unbiased estimates.

\section{Model}

Original version of Danninger's theoretical model follows the classic principal-agent setup: the main fiscal (forecasting) authority (e.g. the ministry of finance) is supposed to act as the Principal, on the contrary the actual tax-collecting authority is supposed to act as the Agent. In the following section the basics of principal-agent theory are depicted. It enables 1) the proper analysis of forecast effectivity and 2) the testing of the statistical significance of Agents effort for better tax collection.

\section{Principal-Agent theory foundations of model}

The base of the theory is the existence of two different utility functions, one's for Principal, second is for Agent. Principal employs the Agent to perform some activities and on the other side Agent is (but only partly) involved in benefits of performed activities. This relation is analyzed under uncertainty concerning the activity results (tax revenue in our case). These results are based on 1) Agent's performance (whether he is doing his job well or bad) but are also 2) influenced by other variables which are not suggestible by Agent. Uncertainty of 1) and 2) induces the limited supervision of Agent's performance by the Principal. Moreover, there is a phenomenon of asymmetric information which limits the supervision too. Uncertainty and asymmetric information mentioned above are stimulus for Agent to act in the way to increase only his benefits (i.e. to maximize Agent's utility function) at the expense of Principal's benefits. The differences in utility functions produce the ineffectiveness of performed activities.

If we resume principal-agent theory, we can conclude, that in some way it can be an appropriate theory to analyze problem of biased forecasts and can help to clarify their rationale. Firstly, as mentioned above, relation between the main fiscal authority and tax-collecting authority is very similar to the principal-agent one. Main fiscal authority provides 
public services (financed from public revenues) under condition of imperfect control over its tax-collecting authorities ${ }^{1}$. Imperfection occurs because of two reasons, 1) direct, everyday control of Agent's performance does not seem to be efficient due to costs of such control and 2) there is some portion of uncertainty concerning the future tax revenue difficult to control by Agent.

The former reason of imperfect control stems from the logic of (not only) Czech tax law. There is (unfortunately) no uniform interpretation of tax acts and every (local) tax-collecting authority can presents all unclear cases in their own way, differently from another authority interpretation. In this situation it is almost impossible for the Principal to control every case and decide whether the Agent is doing a good job. We can sum up that the government is unable to directly observe the activities of tax-collecting authority, and thus cannot verify whether the agent works efficiently or not.

The latter reason of imperfect control can be clarify in this way. Tax revenue is influenced by broad set of variables ${ }^{2}$, from macroeconomic (GDP, private expenditures, price index), microeconomic (price and income elasticity) to social and demographic variables. So some differences between planned and actual revenue are not caused by Agent's bad performance.

\section{Basic elements of model}

As we mentioned above, model utilizes two different utility functions designed to depict the representative behaviour of the main fiscal authority on one side and of the tax-collecting authority on the other side (for the sake of simplicity we will use shorter terms Principal and Agent respectively in the rest of the paper).

The application of principal-agent theory in public finance needs to introduce one another subject, we use term SuperPrincipal, i.e. public, voter. Then we can define three basic functions:

SuperPrincipal utility function can be defined by expression ${ }^{3}$

$$
u=u(C, G, S)
$$

where $C, G-$ private and public consumption, respectively, $S \quad-$ so called Degree of Satisfaction.

Private consumption $C$ is equal to after tax income $(Y-R)$, where $R$ is tax revenue and depends on the real tax rate $t(e)$, which itself is a function of effort (honesty) $e$ by the tax-collecting authority. The tax collection is supposed to be increasing in effort.

The public good $G$ is nonrival in consumption and its production is characterized by economies of scale. Production of $G$ is financed by tax revenue. Model employs following way to express the voter's preferences concerning the public consumption. Model supposes that higher economies of scale (in former model ${ }^{4}$ denoted as $g$ ) in public production mean higher voter's preferences of higher $R$. In other words $g$ measures the effect of increasing

1 Some authors (Danninger, 2005) use term "tax administration" but we prefer term "tax-collecting authority" because it expresses the Agent's performance more clearly.

2 For excellent review of variables see Špalek 2002.

3 In this non-technical paper we decided use a simplified notation, for technical description see Danninger (2005)

4 For extensive discussion of $g$ see Danninger (2005), p. 13. 
returns in producing the nonrival public good and is supposed to be a first parameter which has influence on the probability of Principal's next re-election. It implies that higher $g$ (higher preferences of public consumption $G$ ) means that SuperPrincipal demands more efficient revenue collection (denoted $e$, see later) and higher revenues $R$ to finance the higher level of $G$.

Degree of Satisfaction $(S)$ is defined as follows and can be considered as Principal's utility function

$$
S=(1-c \cdot b) \cdot\left(R^{2}-(R e)^{2}\right),
$$

where $b \quad-$ expresses whether Principal punishes (lays off) Agent $(b=1)$ or not $(b=0)$ in case $R<R e$,

$c \quad$ - denotes how effective is Principal's punishment $(b=1)$ to sustain $\mathrm{S}$ $\operatorname{high}(c=<0,1>)$.

$R, R e$ - actual revenue and revenue expected by Principal, respectively.

Degree of Satisfaction measures the approval of SuperPrincipal with the perceived budget planning performance of the Principal, and captures the effect of government credibility. Introduction of Degree of Satisfaction function is one of the extensions of the classical principal-agent approach derived from public sector theory.

Unforeseen revenue collection in excess of the forecast Re has a positive effect (principal and agent are doing their job effectively), while unexpected revenue shortfalls have a damaging effect on the probability to be re-elected. We can sum up that Principal must take into account (during the next election) the public preferences of consumption $G(g)$ and the degree of Satisfaction (c).

Let's focus on the revenue shortfalls. This situation generates so called reputational costs (which have negative effect on $S$ ). The costs depend on two factors $(b, c)$.

Firstly Principal can partially deflect the SuperPrincipal dissatisfaction on the Agent by laying off some of their employees ( $b=1$ means the decision to lay off, $b=0$ means not to lay off). Principal punishes the Agent for his bad tax-collecting job. It is supposed, $b$ depends on $R^{2}-(R e)^{2}$.

Secondly, the efficiency of lay-off (i.e. how much the fault will be deflected on Agent) depends on how the shortfalls will be perceived by SuperPrincipal. Higher $c$ means the SuperPrincipal believes the shortfall was the Agent's fault rather than Principal's one. So Principal bears only a fraction $(1-c \cdot 1)^{5}$ of reputational loss, the rest is deflect on Agent and does not decrease $S$.

Agent's utility function is defined as

$$
\operatorname{Max}_{e} E(I)=W-f_{1}(\mathrm{Re}, e) \cdot W-f_{2}(e),
$$

where $\operatorname{Max}_{e} E(I)$ - denotes that Agent maximizes his expected income $I$ with respect to effort (denoted as $e$ ),

$W \quad-$ nominal wage,

$f_{1}(R e, e) \quad$ - the likelihood to be fired if $R<R e$,

$f_{2}(e)-$ costs of exerting effort or to being honest.

5 We suppose $b=1$, i.e. Principal punishes Agent. Higher the $R^{2}-(R e)^{2}$ means higher the possibility to loose a job. 
The Agent maximizes income $I$ from wages $W$ minus costs of exerting effort $f_{2}(e)$. Model supposes that ex ante probability for the Agent of being laid off $f_{1}(R e, e)$ is increasing in $\mathrm{Re}$ and decreasing in $e$, i.e. the probability is increasing in $(R e-R)$.

Fig. 1 summarizes finding of model and depicts the influence of level of Re on Agent's utility function and Agent's effort.

\section{Fig. 1: Impact of different levels of $R e$ on effort $e$ and expected income}

$$
W-f_{1}(\operatorname{Re}, e) \cdot W-f_{2}(e)
$$

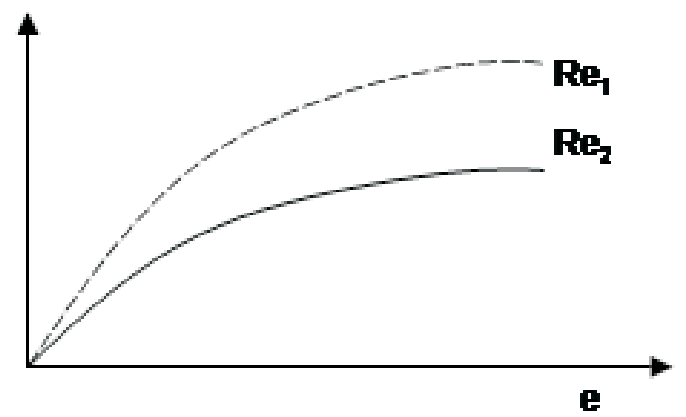

Fig. 1 depicts the utility function in the case of two different revenue forecasts $\left(R e_{1}<R e_{2}\right)$. The function for $R e_{1}$ is higher then one for $R e_{2}$. The rationale is as follows: to reach a specific level of expected income (depicted on $\mathrm{Y}$ axis) it is necessarily to exert some effort to meet the forecasted revenue Re. Higher the forecasted revenue is set up, higher the effort must be exerted, to reach forecasted revenue and also the income, ceteris paribus.

\section{Model implications for public revenue forecasting process}

Implications of principal-agent approach to public revenue forecasting can be sum up as follows.

The tax-collecting authority chooses the level of its unobservable performance effort $e$. This level is supposed to determine the revenue available for the government to fulfil its functions (public expenditure programs).

The efficiency of public services (sustained by government) is under public scrutiny. The public (voter) is critical of low performance, he dislikes large revenue shortfalls relative to budget estimates. It generates pressure to penalize responsible officials (Principal and Agent). Thus, the tax-collecting authority has an incentive not to deviate too much from the official revenue forecast.

Implications mentioned above allow to fiscal authority under some conditions to use overstated forecasts as an incentive device to increase Agent's performance effort at the cost of producing unrealistic forecasts. As long as the benefits from increasing effort outweigh the costs of producing ex post forecast errors, the government will produce overstated revenue forecasts. Cost of Principal's reputational loss (see Degree of Satisfaction function discussed above) is determined by parameter $b \cdot c$, i.e. Principal shifts part of the reputational damage on its Agent. To analyze rationale of biased forecast completely, we 
must also take into account the parameter $g$, which describes the SuperPrincipal preferences concerning the public consumption. Higher the preferences are, higher the incentive for Principal to overstated revenue forecasts to increase the level of publicly financed consumption is supposed.

So overstated forecasts occur, if “... public approval is more sensitive to the efficiency of public service [see discussion of parameter $g$ in paper above], while the credibility of budget plans bears little weight on the approval rate. This will more likely be the case if opportunities for rent seeking in the revenue administration are high or oversight is low, as in the case when the revenue administration operates independently from the ministry of finance. If, on the other hand, effort is already at a high level and public approval is affected strongly by the credibility of budget plans, then understating forecast may be rational." (Danninger, 2005, p. 6).

\section{Empirical analysis}

Empirical testing of behavioural models is difficult. Contemporary modelling is highly sophisticated and relations are supposed to be stochastic so very complex datasets are necessary to employ during testing of model structures. Within the paper preparation we did not find in literature any serious attempt to test implications of Danninger's model.

There are two basic trends in current empirical investigation. The first kind of investigation focuses on testing hypothesis whether there are statistically significant biased revenue forecasts or not (Špalek, 2002, Danninger, 2002, Klazar, 2003). Špalek (2002) employs the regression analysis and time series analysis and Klazar (2003) employs the nonparametric methods. They both confirm that the overall forecasts (sum of all taxes) were during the last decade unbiased in the Czech Republic.

The second kind tries to test whether the Agent is independent of Principal by analysing of the labour market and the labour code or whether the Principal is independent of SuperPrincipal by testing the political structures and voting systems (Bretschneider, Gorr, 1992).

In this paper we test one of two ${ }^{6}$ necessary assumptions for rational overestimated tax forecast. We test statistical evidence of the implication that the tax revenue depends on the real tax rate $t(e)$, which itself is a function of effort (honesty) $e$ by the tax-collecting authority.

The empirical model is defined as follows

$$
\frac{R_{t} i-R_{t-1} i}{R_{t-1} i}=a+b\left(\pi_{i}\right)+c \cdot\left(T A_{i}\right),
$$

where $\frac{R_{t} i-R_{t-1} i}{R_{t-1} i}$ - relative increase of tax revenue between $\mathrm{t}$ and $\mathrm{t}-1$ period in $R_{t-1} i \quad$ region i,

$\pi_{i} \quad-\quad$ the rate of unemployment in region $\mathrm{i}$,

$\mathrm{TA}_{\mathrm{i}} \quad-$ the possibility for tax subject (tax payer) that tax audit will be carried out in his business.

Note: We do not use time term on the right side for the sake of simplicity.

6 The second is: Principal can significantly motivate Agent for exerting higher effort. 
We choose as dependent variable the relative annual increase of tax revenue. It can be a good proxy of $(R-R e) / R e$ (relative measure of over/understated forecast). We suppose the actual revenue $R_{t-1}$ is the best estimate of ex ante (expected) $R e_{t}$. The underlying rationale of such assumption is that $R e_{t}$ is derived by Principal with some kind of extrapolation forecasting method (time series analyses, regression analyses, VAR or Vector Error Correction models). So we bypass the lack of information about Re and the data for Corporate Income Tax for 16 tax-collecting authorities from the years 2004 and 2005 are sufficient for our analysis.

Model anticipates that the real channels of Principal's control of Agent's effort are unobservable, so we have to choose some proxy variables. The question is what can motivate the Agent to do a good (better) job?

As the first independent variable was chosen the rate of unemployment in region $\mathrm{i}\left(\pi_{\mathrm{i}}\right)$. It can be a good proxy for the likelihood to be laid off if $R<R e$ (see equation 3 ). The rationale is that the Agent's effort increases in the likelihood to be laid off, because the fired employee will not be able to find a new job immediately. ${ }^{7}$

The number of Tax Audits and On-the-Spot Investigations was chosen as the second independent variable. ${ }^{8}$ Variable is defined as

$$
\begin{aligned}
T A_{i}= & \frac{\text { number of Tax Audits and On }- \text { the }- \text { Spot Investigations }}{\text { number of tax payers }} \\
& \text { in region } i \text { during the } t \text { period. }
\end{aligned}
$$

We suppose this variable can be a good proxy for the level of Agent's effort.

\section{Data}

We analyze data from 16 tax-collecting authorities situated equally all over the Czech Republic (see Appendix A). We tried to choose similar authorities as much as possible (i.e. similar number of tax subjects and similar number of authority's employees). However we were limited by availability of data concerning tax revenue.

We collected data for Corporate Income Tax for 16 tax-collecting authorities from the years 2004 and 2005. Number of tax audits and number of tax payers were kindly provided by the Department of tax administration of Ministry of finance and from the Annual reports of the tax-collecting authorities centre $(2005,2006)$.

\section{Results from regression analysis}

Original regression results are depicted in Table 1. DR is $\left(R_{t} i-R_{t-1} i\right) / R_{t-1} i, U N E M P L_{i}$ is $\pi_{i}$ from the equation (4).

$7 \quad$ We can abstract from the possibility that the rate of unemployment affects the trends of tax revenue. The rate of unemployment was stable over the tested period and therefore did not affect tax revenue directly.

8 Tax audit is to establish and examine the tax base or other circumstances decisive for correct determination of the tax. On-the-Spot investigations are used for examination of facts necessary for conducting the tax proceeding. 
Tab. 1: Original regression results

Dependent Variable: $D R$

Method: Least Squares

Included observations: 16

$D R=C(1)+C(2) \cdot U N E M P L+C(3) \cdot T A$

\begin{tabular}{|l|c|l|l|c|}
\cline { 2 - 5 } \multicolumn{1}{l|}{} & Coefficient & Std. Error & t-Statistic & Probability \\
\hline$C(1)$ & 0.007710 & 0.013690 & 0.563173 & $\mathbf{0 . 5 8 2 9}$ \\
$C(3)$ & 0.213042 & 0.093236 & 2.284975 & $\mathbf{0 . 0 3 9 8}$ \\
\hline R-squared & 0.432201 & 0.176452 & 2.449391 & $\mathbf{0 . 0 2 9 2}$ \\
Adjusted R-squared & 0.523634 & $\mathbf{0 . 4 5 0 3 4 7}$ & Mean dependent var. & 0.056154 \\
S.E. of regression & 0.014434 & Akaike info criterion & $\mathbf{- 5 . 4 7 1 1 5 8}$ \\
Sum squared resid. & 0.002708 & Schwarz criterion & $\mathbf{- 5 . 3 2 6 2 9 8}$ \\
Log likelihood & 46.76926 & F-statistic & 7.144976 \\
Durbin-Watson & 2.766530 & Prob(F-statistic) & 0.008065 \\
stat. & \multicolumn{4}{|c}{} \\
\hline
\end{tabular}

Diagnostic test for serial correlation of residuals ${ }^{9}$

\begin{tabular}{|l|l|l|l|}
\hline Breusch-Godfrey Serial Correlation LM Test: \\
\hline Obs*R-squared & 2.607976 & Probability & 0.271447 \\
\hline
\end{tabular}

Diagnostic test for normality of residuals ${ }^{10}$

\begin{tabular}{|l|l|l|l|}
\hline \hline Jarque-Bera & 0.937224 & Probability & 0.625870 \\
\hline
\end{tabular}

The estimated coefficients are not statistically significant (see very high Prob value), but with t-statistic values well in excess of 2 for unemployment and tax audit variables $(C(2)$ and $C(3)$ respectively). The overall fit of regression, as measured by the value of Adjusted R-squared $(=0.45)$, indicates a medium fit of data.

Prob value for constant $C(1)$ suggests low statistical significance of constant term and the exclusion (dropping) of this term from regression can improve the specification of model. Moreover, Adjusted R-squared which penalizes the plain R-squared for the addition of repressor can be helpful for us to reveal the variables which do not contribute to the explanatory power of the model.

9 The null hypothesis is for no serial correlation. The (effectively) zero $(<0.05)$ probability value strongly indicates the presence of serial correlation of the residuals. So in this case $(0.05<0.2715)$ residuals seem to be not correlated.

10 Jarque-Bera is a test statistic for testing whether the series (residuals) is normally distributed. A small probability value leads to the rejection of a normal distribution. So in this case $(0.05<0.6259)$ we do not reject the hypothesis that residuals are normally distributed. 
The estimation results for modified regression are depicted on the Table 2.

Tab. 2: Modified regression model results

Dependent Variable: $D R$

Method: Least Squares

Sample: 116

Included observations: 16

$D R=C(2) \cdot U N E M P L+C(3) \cdot T A$

\begin{tabular}{|l|c|l|l|c|}
\cline { 2 - 5 } \multicolumn{1}{c|}{} & Coefficient & Std. Error & t-Statistic & Probability \\
\hline$C(2)$ & 0.233005 & 0.084106 & 2.770365 & $\mathbf{0 . 0 1 5 0}$ \\
\hline R-squared & 0.510111 & 0.106825 & 4.775196 & $\mathbf{0 . 0 0 0 3}$ \\
Adjusted R-squared & 0.512012 & Mean dependent var. & 0.056154 \\
S.E. of regression & 0.014077 & Akaike info criterion & $\mathbf{- 5 . 5 7 2 0 5 4}$ \\
Sum squared resid. & 0.002774 & Schwarz criterion & $\mathbf{- 5 . 4 7 5 4 8 0}$ \\
Log likelihood & 46.57643 & F-statistic & 14.68924 \\
Durbin-Watson & 2.725238 & Prob(F-statistic) & 0.001829 \\
stat. & & & \\
\hline
\end{tabular}

Diagnostic test for serial correlation of residuals

Breusch-Godfrey Serial Correlation LM Test:

\begin{tabular}{|l|l|l|l||}
\hline Obs*R-squared & 2.337238 & Probability & 0.310796 \\
\hline
\end{tabular}

Diagnostic test for normality of residuals

\begin{tabular}{|l|l|l|l||}
\hline \hline Jarque-Bera & 1.389677 & Probability & 0.499155 \\
\hline
\end{tabular}

Dropping of the constant term from original regression improves the specification of model. All regressors are statistically significant at $5 \%$ level. Moreover goodness of fit measured by Adjusted R-squared increased (from 0.450 to 0.477 ). Also lower values for both the Akaike and the Schwarz information criteria ${ }^{11}$ indicate that the latter reduced model may be preferred. ${ }^{12}$

Coefficients of both regressions have expected signs (are positive) and confirm our working hypothesis that the higher risk of unemployment and the higher relative number of tax audits performed by tax-collecting authorities lead to higher tax revenues. We can conclude that the tax revenue generated from Corporate Income Tax depends significantly on rate of unemployment and on the possibility to be investigated by the tax-collecting author-

11 The information criteria provide measures of information that strikes a balance between this measure of goodness of fit and parsimonious specification of the model.

12 Tests for serial correlation and normality in the residuals from estimated equations were performed (see Appendix B). Presented model meets all these criteria. 
ity (as a proxy of its effort (honesty)). It seems the overstated revenue forecast can be rational to increase the tax revenue under the circumstances of Czech Republic.

\section{Conclusions}

This paper presents an explanation for rationally biased revenue forecasts based on institutional weaknesses. The principal-agent approach to the analysis is employed to show, that the government's inability to control the performance of tax-collecting authorities can lead to rationally overstated revenue forecasts. Paper provides supportive case study evidence from recent budget revenue trends. It seems the revenue forecasting can be used as an incentive device in Czech Republic.

\section{References}

[1] AUERBACH, A. J. (1999): On the Performance and Use of Government Revenue Forecasts. National Tax Journal, 1999, Vol. 52, No. 12, pp. 767-782.

[2] BRETSCHNEIDER, S. - GORR, W. (1992): Economic, Organizational, and Political Influences on Biases in Forecasting State Sales Tax Receipts. International Journal of Forecasting, Vol. 7, No. 4, pp. 457-466.

[3] Czech Statistical Office (2006): Trends in economic activities of Czech population in 2005. [on-line], Praha, Czech Statistical Office, c2006, [cit. 31. 5. 2006], $<\mathrm{http}$ ://www.czso.cz/csu/csu.nsf/ainformace/6FF900432A37>.

[4] DANNINGER, S. (2005): Revenue Forecasts as Performance Targets. [on-line], Washington, D.C., IMF Working paper 14, c2005, [cit. 31. 5. 2006], $<$ http://www.imf.org/external/pubs/ft/wp/2005/wp0514.pdf $>$.

[5] DANNINGER, S. - KYOBE, A., (2005) Revenue Forecasting - How is it done? Results from a Survey of Low-Income Countries. [on-line], Washington, D.C., IMF Working paper 24, c2005, [cit. 31. 5. 2006], $<$ http://www.imf.org/external/pubs/ft/wp/2005/wp0524.pdf $>$.

[6] DANNINGER, S. - KYOBE, A. - CANGIANO, M. (2005): The Political Economy of Revenue-Forecasting Experience from Low-Income Countries. [on-line], Washington, D.C., IMF Working paper 24, c2005, [cit. 31. 5. 2006], $<$ http://www.imf.org/external/pubs/ft/wp/2005/wp0502.pdf $>$.

[7] FEENBERG, D. R. - GENTRY, W. - GILROY, D. - ROSEN, H. S. (1989): Testing the Rationality of State Revenue Forecasts. Review of Economics and Statistics, 1989, Vol. 42, pp. 429-440.

[8] GOLOSOV, M. - King, J. (2002): Tax Revenue Forecasts in IMF-Supported Programs. [on-line], Washington, D.C., IMF Working paper 14, c2005, [cit. 31. 5. 2006], $<\mathrm{http}: / / w w w . i m f . o r g / e x t e r n a l / p u b s / f t / w p / 2002 / w p 02236 . p d f>$.

[9] GROSSMAN, S. J. - HART, O. D. (1983): An Analysis of Principal-Agent Problem. Econometrica, Vol. 51, No. 1, pp. 7-46.

[10] HOLMSTRÖM, B. (1979): Moral Hazard and Observability. Bell Journal of Economics, 1979, Vol. 10, No. 1, pp. 74-91. 
[11] KLAZAR, S. (2003): Efektivnost predikce daňových přijmů v ČR. (Rationality of public revenue forecasting process in Czech Republic.) (Ph.D. Thesis). Praha, University of Economics, Prague, 2003.

[12] LASTER, D. - BENNETT, P. - GEOUM, I. S. (1999): Rational Bias in Macroeconomic Forecasts. The Quarterly Journal of Economics, Vol. 114, No. 1, pp. 293-318.

[13] MFCR (2005): Annual report of the tax-collecting authorities centre. Praha, Ministry of Finance of Czech Republic, 2005.

[14] MFCR (2006): Annual report of the tax-collecting authorities centre. Praha, Ministry of Finance of Czech Republic, 2006.

[15] PIKE, T. - SAVAGE, D. - GILES, C. - HALL, J. (1998): Forecasting PSBR outside government: the IFS perspective. Fiscal Studies, 1998, Vol. 19, No.1, pp. 83-100.

[16] PINDYCK, R. S. - RUBINFELD, D. L. (1991): Econometric Models and Economic Forecasts. New York, McGraw-Hill, 1991.

[17] Quantitative Micro Software (2005): EViews User's Guide. Quantitative Micro Software, 2005.

[18] ŠPALEK, J. (2002): Forecasting of public revenues. (PhD thesis). Brno, Masaryk University, Faculty of Economics and Administration, 2002.

[19] ZELLNER, A. (1986): Biased Predictors. Rationality and the Evaluation of Forecasts. Economic Letters, 1986, Vol. 21, No. 1, pp. 45-48. 
Appendix A: Data

\begin{tabular}{|l|r|r|c|}
\hline \multicolumn{1}{|c|}{ Tax-Collecting Authority (Region "i") } & \multicolumn{1}{c|}{$\boldsymbol{T A}_{\boldsymbol{i}}$} & \multicolumn{1}{c|}{$\boldsymbol{U N E M P \boldsymbol { I } _ { \boldsymbol { i } }}$} & \multicolumn{1}{c|}{$\boldsymbol{D} \boldsymbol{R}_{\boldsymbol{i}}$} \\
\hline Beroun & $6.81 \%$ & $6.10 \%$ & $6.96 \%$ \\
\hline Bruntál & $8.58 \%$ & $15.50 \%$ & $7.18 \%$ \\
\hline Český Krumlov & & & \\
\hline Děčín & $10.56 \%$ & $6.00 \%$ & $5.30 \%$ \\
\hline Hodonín & $5.99 \%$ & $14.50 \%$ & $7.92 \%$ \\
\hline Jilemnice & $8.58 \%$ & $8.70 \%$ & $9.04 \%$ \\
\hline Jindřichův Hradec & $7.50 \%$ & $6.90 \%$ & $5.04 \%$ \\
\hline Karviná & $10.17 \%$ & $6.00 \%$ & $6.81 \%$ \\
\hline Klatovy & $8.06 \%$ & $15.50 \%$ & $8.28 \%$ \\
\hline Kolín & $6.32 \%$ & $5.60 \%$ & $3.42 \%$ \\
\hline Náchod & $2.83 \%$ & $4.30 \%$ & $2.62 \%$ \\
\hline Praha-Východ (Prague-East) & $7.76 \%$ & $6.90 \%$ & $4.77 \%$ \\
\hline Semily & $6.52 \%$ & $6.10 \%$ & $4.94 \%$ \\
\hline Slaný & $5.81 \%$ & $14.50 \%$ & $4.38 \%$ \\
\hline Tachov & $2.91 \%$ & $4.30 \%$ & $2.59 \%$ \\
\hline Vyškov & $5.88 \%$ & $5.60 \%$ & $5.89 \%$ \\
\hline & $8.41 \%$ & $8.70 \%$ & $4.71 \%$ \\
\hline
\end{tabular}

\footnotetext{
Note: $T A_{i} \quad-$ number of Tax Audits and On-the-Spot Investigations $) /(\operatorname{tax}$ subjects) in region $i$ (MFCR 2005, MFCR, 2006),

$D R_{i} \quad-$ relative increase of tax revenue from Corporate Income Tax between 2005 and 2004 in region $i$ (Czech Statistical Office, 2006),

$U N E M P L_{i} \quad$ - the rate of unemployment in region $i$ in 2005 .
} 


\section{Appendix B: Regression models and tests of their appropriate specification}

Dependent Variable: $D R$

Method: Least Squares

$D R=C(1)+C(3) \cdot T A$

\begin{tabular}{|l|l|l|l|c|}
\cline { 2 - 5 } \multicolumn{1}{c|}{} & Coefficient & Std. Error & t-Statistic & Probability \\
\hline$C(1)$ & 0.019603 & 0.014446 & 1.356994 & 0.1963 \\
\hline$(3)$ & 0.518936 & 0.196590 & 2.639687 & 0.0194 \\
\hline R-squared & 0.332314 & Mean dependent var. & 0.056154 \\
Adjusted R-squared & 0.284622 & S.D. dependent var. & 0.019468 \\
S.E. of regression & 0.016466 & Akaike info criterion & -5.258526 \\
Sum squared resid. & 0.003796 & Schwarz criterion & -5.161953 \\
Log likelihood & 44.06821 & F-statistic & 6.967950 \\
$\begin{array}{l}\text { Durbin-Watson } \\
\text { stat. }\end{array}$ & 2.723185 & Prob(F-statistic) & 0.019416 \\
\hline
\end{tabular}

Diagnostic test for serial correlation of residuals

Breusch-Godfrey Serial Correlation LM Test:

\begin{tabular}{|l|l|l|l}
\hline Obs*R-squared & 2.348399 & Probability & 0.309066 \\
\hline
\end{tabular}

Diagnostic test for normality of residuals

\begin{tabular}{|l|l|l|l|}
\hline \hline Jarque-Bera & 1.389677 & Probability & 0.499155 \\
\hline
\end{tabular}


Dependent Variable: $D R$

Method: Least Squares

$D R=C(1)+C(2) \cdot U N E M P L$

\begin{tabular}{|l|c|l|l|c|}
\cline { 2 - 5 } \multicolumn{1}{l|}{} & Coefficient & Std. Error & t-Statistic & Probability \\
\hline$C(1)$ & 0.034001 & 0.009900 & 3.434480 & 0.0040 \\
$C(2)$ & 0.262170 & 0.106072 & 2.471618 & 0.0269 \\
\hline R-squared & 0.303791 & Mean dependent var. & 0.056154 \\
Adjusted R-squared & 0.254062 & S.D. dependent var. & 0.019468 \\
S.E. of regression & 0.016814 & Akaike info criterion & -5.216694 \\
Sum squared resid. & 0.003958 & Schwarz criterion & -5.120120 \\
Log likelihood & 43.73355 & F-statistic & 6.108898 \\
$\begin{array}{l}\text { Durbin-Watson } \\
\text { stat. }\end{array}$ & 2.419126 & Prob(F-statistic) & 0.026900 \\
\hline
\end{tabular}

Diagnostic test for serial correlation of residuals

Breusch-Godfrey Serial Correlation LM Test:

\begin{tabular}{|l|l|l|l}
\hline Obs*R-squared & 1.572666 & Probability & 0.455512 \\
\hline
\end{tabular}

Diagnostic test for normality of residuals

\begin{tabular}{|l|l|l|l|}
\hline \hline Jarque-Bera & 0.240492 & Probability & 0.886702 \\
\hline
\end{tabular}




\title{
Predikce daňových př́ijmů v podmínkách nedokonalé kontroly daňových úřradů
}

\author{
Stanislav Klazar
}

\begin{abstract}
Abstrakt
Příspěvek analyzuje možné důvody, proč státní (vládní) instituce někdy záměrně nadhodnocují nebo podhodnocují odhady veřejných př́jmů. Pomocí modifikovaného Danningerova modelu je odvozeno, že důvodem nadhodnocených předpovědí může být snaha motivovat instituce provádějící výběr daně $\mathrm{k}$ vyšší efektivnosti. $\mathrm{V}$ př́íspěvku je provedena empirická analýza závislosti míry přestřelení odhadu na 1) míře nezaměstnanosti $\mathrm{v}$ daném regionu a 2) relativním počtu provedených daňových kontrol v regionu. Výsledky naznačují, že jistá míra přestřelení odhadu může být využita v České republice ke zvyšování efektivnosti výběru daní finančními úrady.
\end{abstract}

Klíčová slova: prognóza příjmu; principál; agent; zkreslená předpověd'; teorie zastoupení.

\section{Tax revenue prediction under condition of imperfect control over tax-collecting authority}

\begin{abstract}
Public revenue forecasts should be accurate and unbiased, it means they should be the best estimates (in statistical view) of expected receipts. This paper analyzes the possible reasons for biased (overestimated or underestimated) tax revenue forecasts. Our modification of Danninger's theoretical model demonstrates that systematically (over a long period) and intentionally (deliberately) biased revenue forecasts can be result of the government's (principal's) attempt to increase the effort of tax-collecting authority (agent) to collect revenue. We carry out empirical analysis to test one of the model implications - relation between effort and relative grow of tax revenue. We use data from the years 2004 and 2005 for Corporate Income Tax collected in 16 tax-collecting authorities.
\end{abstract}

Key words: revenue forecast; principal; agent; biased forecast; agency theory.

JEL classification: $\mathrm{H} 2, \mathrm{H} 3$. 